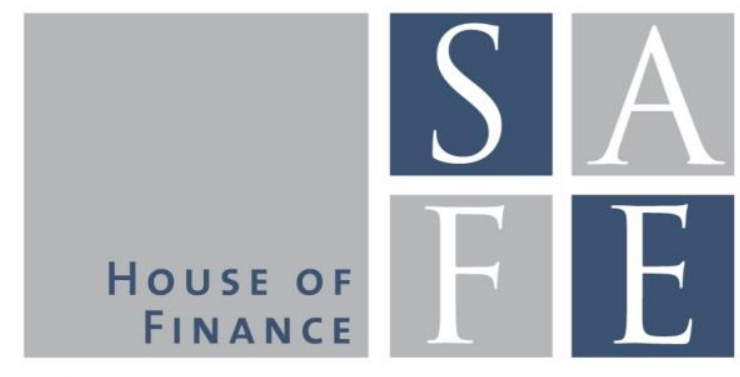

WORKING PAPER SERIES

Julia Hirsch - Uwe Walz

\title{
Financial constraints, newly founded firms and the financial crisis
}

SAFE Working Paper No. 191

SAFE I Sustainable Architecture for Finance in Europe A cooperation of the Center for Financial Studies and Goethe University Frankfurt 


\section{Non-Technical Summary}

It is widely accepted that the continuous formation of new firms is of substantial importance with respect to their contribution to job creation processes and innovation within dynamic economies. Therefore, sufficient access to financial resources is needed in order to enable these firms to get established as well as to grow and develop. External financial resources are viewed as the bottleneck for new firms as they are confronted with more pronounced information asymmetries in comparison to their corporate counterparts.

In this paper, the impact of financial constraints in general and during the recent financial crisis in particular is analyzed with respect to the financing and investment decisions of newly founded firms. While previous studies focus on a key aspect of corporate finance, they rely on firms which are either public or when being private have been in the market at least for some time. Rather than focusing on the narrow segment of start-up companies, i.e. young, innovative and (very) fast growing companies with potential access to venture capital financing, the analysis of this paper utilizes data which cover newly founded French firms from all industries of the manufacturing sector founded between 2004 and 2006. These newly founded firms are not only the most vulnerable ones but also the ones which may contribute most to the dynamics of the economy. Hence, this analysis closes an important gap by investigating the relationship between the financial sector and this segment of the real economy.

The analysis shows that the financial crisis reduced overall debt financing as well as different types of specific financing sources such as long-term debt, bank- as well as trade-credit financing. Furthermore, a negative effect of financial constraints on overall debt financing as well as trade-credit financing is derived. With respect to bank debt, financially constrained firms are found to repay less and show lower positive net financing amounts than their financially non-constrained counterparts. Interestingly, financially constrained firms were affected to a smaller degree by the financial crisis than their unconstrained counterparts. Furthermore, the financial crisis reduced the investment levels though to a lower degree compared with the reduction caused by financial constraints. Finally, the impact of the financial crisis on the investment behavior did not differ between financially constrained and financially nonconstrained firms. Based on these findings, this analysis contributes importantly to a better understanding of the financing and investment policies of newly founded firms in the wake of external shocks and financial constraints. 


\title{
Financial constraints, newly founded firms and the financial crisis*
}

\author{
Julia Hirsch ${ }^{\dagger}$ \\ Autonomous University of Queretaro, Mexico \\ Uwe Walz \\ Goethe University Frankfurt, CFS/SAFE and ECGI \\ This version: December 14, 2017
}

\begin{abstract}
This paper aims to analyze the effects of financial constraints and the financial crisis on the financing and investment policies of newly founded firms. Thereby, the analysis adds important new insights on a crucial segment of the economy. We make use of a large and comprehensive data set of French firms founded in the years 2004-2006, i.e. well before the financial crisis. Our panel data analysis shows that the global financial crisis imposed a shock (mostly demand-driven) on the financing as well as on the investments of these firms. Moreover, we find that financially constrained firms use less external debt financing and invest smaller amounts. They also rely on less trade credit. With regard to bank financing, newly founded firms which are more financially constrained accumulate less bank debt and repay initial bank debt slower than their non-financially constraint counterparts. Finally, we find that financially constrained firms are affected to a smaller degree by the financial crisis than their less financially constrained counterparts.
\end{abstract}

Keywords: financial constraints, financial crisis, financing decisions, investment decisions, newly founded firms

JEL classification: D92, G32

*We are grateful to IODS for granting us access to the Altares data base. We are also thankful to the LOEWE Center Sustainable Architecture for Finance in Europe (SAFE), in particular, its visitor program for financial support for our research.

$\dagger$ Julia Hirsch, Autonomous University of Queretaro, Mexico, Paseo de las Campanas s/n, Queretaro, Qro, Mexico, E-mail: julia.hirsch@uaq.mx

${ }^{\ddagger}$ Uwe Walz, Dept. of Economics, Theodor-W-Adorno Platz 4, 60323 Frankfurt, Germany, E-mail: uwalz@econ.uni-frankfurt.de. 


\section{Introduction}

The creation of new firms is one of the crucial determinants of dynamic economies contributing not only to job creation but also to innovation (Kortum and Lerner (2001)). One of the key inputs for these firms are financial resources which allow them not only to start their business but also to survive and grow. Due to significantly more pronounced informational asymmetries of newly founded firms as compared to their corporate counterparts (see, e.g., Denis (2004)), external financial resources are often viewed as a crucial bottleneck of this type of firms. Given this important linkage between the financial and the real sector of the economy, it is important to understand the effects of financial frictions and of external shocks originating from the financial sector - such as the recent financial crisis - on the financing and investment behavior of newly founded firms.

The main aim of the paper is to investigate the impact of financial constraints in general and during the financial crisis, in particular, on the financing and investment decisions of newly founded firms. To be more precise, we aim to address the following two main research questions. First, what are the effects of financial constraints in general and those potentially emerging from a financial crisis on the financing structure of newly founded firms? Second, what are the effects on the investment policies of these newly founded firms? We thereby aim to contribute to both the literature focusing on the effects of financial constraints on the firms' financing decisions and their investment policies as well as to the literature analyzing the impact of the financial crisis on these decisions.

We build on a (very) large body of literature investigating the impact of the firms' financial constraints on their financing structure (see e.g. Banerjee and Duflo (2014)), their investment policies (see e.g. Almeida and Campello (2007), Hennessy et al. (2007), and Czarnitzki and Hottenrott (2011) ) as well as their performance (see e.g. Bottazzi et al. (2014), Li (2011), and Livdan and Zhang (2009)). The underlying notion of this literature is that financially constrained firms have limited access to external finance hindering them to invest in positive net-present-value projects and hence, reducing firm growth as well as performance. In order to investigate these issues, the literature has 
developed a number of measures which are used as proxies for financial constraints (see e.g. Kaplan and Zingales (1997) and Whited and Wu (2006)). This approach has recently been criticized by Farre-Mensa and Ljungqvist (2016) who argue that the financial constraint measures employed in the literature are not suitable for public firms and do not properly measure financial constraints . They use the Kaplan-Zingales, Whited-Wu, and Hadlock-Pierce indices to show that firms which are indicated to be financially constrained according to these measures have had no trouble raising debt, when their demand for debt increased, and are not affected by changes in the supply of bank loans. In contrast, however, they show that private firms seem, indeed, to be financially constrained. Thus, adopting these measures in our context seems to be less problematic.

Before and especially in the aftermath of the financial crisis 2007-2008, a significant number of studies have focused on the consequences of the demand and supply shocks caused by the financial crisis on the firms' financing and investment policies. One of the main objectives of these papers is to investigate the consequences of shocks on bank lending abilities for corporate financing as well as performance. In this line, Chava and Purnanandam (2011) investigate the effects of the Russian financial crisis on bank-dependent US firms and show large significant negative effects of the crisis on these firms relative to their counterparts with access to the public debt market. Duchin et al. (2010) investigate the effects of the global financial crisis $2007 / 8$ on corporate investment in the US and find a significant negative effect of the supply shock in the financial sector on corporate investments. This decline is most pronounced for firms that have low cash reserves or high net short-term debt, are financially constrained, or operate in industries dependent on external finance. A contrasting result emerges from Kahle and Stulz (2013) who shed doubts on the supply shock channel during the financial crisis. In particular, they find that bank-dependent firms do not decrease capital expenditures more than comparative non bank-dependent firms in the first year of the crisis and that the decrease in net debt issuance for bank-dependent firms is not greater than for the firms of the comparison group. However, the overall evidence seems to point to a shock in the supply of intermediated credit by banks and other financial intermediaries in the recent financial crisis which is channeled into the real 
sector (see Adrian et al. (2013)).

While all these studies focus on a key aspect of corporate finance, they rely on firms which are either public or when being private have been in the market at least for some time. In contrast to these two strands of the literature, we concentrate on newly founded firms which are most likely to be affected by financial constraints and shocks on the financial sector. These newly founded firms are not only the most vulnerable ones but also the ones which may contribute most to the dynamics of the economy. Hence, we close an important gap by investigating the relationship between the financial sector and this segment of the real economy.

We investigate our research questions by using a comprehensive sample of French firms from the manufacturing sector which have been founded in the years before the financial crisis, namely in 2004, 2005, and 2006. These firm have to provide detailed balance sheet information which allows us to investigate the effects of financial constraints as well as of the financial crisis on the firms' financing policies as well as their investment decisions. In order to identify financial constraints we make use of financial constraint indices developed in the literature (such as the index of Whited and $\mathrm{Wu}$ (2006) and of Hadlock and Pierce (2010)) and adapt them for non-listed, newly founded firms. In addition, we investigate the differential effect of the financial crisis on more and less financially constrained firms in order to enhance the analysis of the impact of the financial crisis and financial constraints (see, in particular, Chava and Purnanandam (2011) and Campello et al. (2010)). Once again, while the mentioned papers address established and/or listed firms, we focus on a very different segment of the corporate landscape, newly founded firms with all their different features.

Our analysis allows us to draw the following conclusions. First, we find that the global financial crisis imposed an adverse shock on the financing policies as well as the investment policies of our newly founded firms. All sources of financing as well as investment are negatively affected. In particular, with respect to bank financing, our results point in the direction of a demand rather than a supply shock. With regard to the impact of financial constraints we find typically a negative effect: financially constrained firms use less trade credit financing and less total debt financing. With regard to bank financing the pattern is similar but a bit more complicated. Finan- 
cially constrained firms accumulate relatively less bank financing in the period after their foundation. In the sample of those firms which pay back their bank debt in the post-founding years, financially constrained firms are the ones which are paying back significantly more slowly than their non-financially constrained counterparts. Finally, when looking at the differences of the impact of the financial crisis between financially constrained and unconstrained firms, we find that financially constrained firms are less affected. This holds for all different financing sources.

The paper is organized in 4 sections. In the next section we describe our data sample and discuss its institutional background. In the third section, we analyze the impact of financial constraints and the financial crisis on the financing structures of our newly founded firms. Furthermore, this section investigates the corresponding consequences on the investment behavior of our firms while the last section concludes.

\section{Sample selection and description}

\subsection{Sample selection}

Our data is based on the requirement of French legislation that firms must publish their financial statements. This requirement is part of the French commercial code (code de commerce) and applies to all firms which are a legal entity with limited liability as well as all partnerships (cf. SPAF (2015)). With the exception of individual entrepreneurs (mainly self-employed people in trading and in commerce), this basically covers all French firms. Since we focus our analysis on the manufacturing sector in which individual entrepreneurs are rather rare, we conjecture that this legal requirement covers the full sample of all French firms with the exception of those firms, which intentionally do not report their financial statements in exchange for a fine to be paid to the French authorities.

The financial information reported by the firms is accessible via the Altares database (a subsidiary of Dun \& Bradstreet) which is part of the IODS (Insead OEE data services) data platform. The database contains 2,500,000 firms in France and its overseas territories. Given this amount as well as the number of newly founded firms on the 
platform, we consider it a fairly complete representation of all French firms. The information provided by Altares supports this conjecture (see Altares (2015)).

Our data sample covers all firms in the Altares database, which were founded in either 2004, 2005, or 2006 and that had a balance sheet available in the year of the founding or the subsequent year. We focus on the manufacturing sector in which firms have French activities classification codes (NAF II) between 20 and 29. We use information on firm characteristics as well as all balance sheets from the founding year onward until 2013. We allow for at most one year in which there is no balance sheet information available for the particular firm. We adopt this procedure as we need to have sufficient observations for each firm both before, during and after the financial crisis in order to be able to compare the financing and investment decisions across the different periods. These conditions result in a sample of 2,607 firms. We also include those firms, which had been liquidated as of 2013. This procedure increases our sample to 2,620 firms. For missing balance sheet data in a given year, we use the average between the year before and the year after. We use this procedure for 683 firm-year observations. For the remaining observations, we rely on a 12-month reporting window. ${ }^{1}$ In a further step, we calculate all of the financing decision ratios: share capital to total assets, total debt to total assets, long-term debt to total assets, loans from credit institutions to total assets, and trade credit to total assets. In order to avoid extreme outliers (which are mainly due to very pronounced negative earnings), we drop all firms for which one of these ratios exceeds at least once a level of two. Hence, our final sample comprises 2,456 firms.

When comparing our sample size with the overall cohort size we find that our sample covers a very significant part of the overall cohort. Using official statistics of the French National Institute of Statistics and Economic Studies (INSEE), we observe that there were founded slightly more than 123,000 (in 2004), 127,000 (in 2005), and 137,000 (in 2006) non-individual-entrepreneurial firms in France in the respective years (see ?) of which less than five percent stem from our industries. This amounts to approximately 6,000 newly founded firms in each of these three years. As we further

\footnotetext{
${ }^{1}$ Only in a few cases do balance sheets deviate from the 12 month reporting window and have a length of 3 to 21 months. In the year after the founding year we even have two (three) firms with balance sheet lengths of 1 and 24 months, respectively.
} 
exclude those firms which were liquidated in the early years, we can conjecture that our sample size is very similar to the one predicted by the data of ?. Nevertheless, when analyzing the financing and investment decisions we have to be aware that we are only looking at the successful firms which survived both the first years as well as the financial crisis.

For all these firms, we have detailed information on the balance sheets and the profit and loss statements for each respective year. Besides industry characteristics, we have information on the legal form of the firm as well as on the number of employees and its detailed location. This provides us with information on a number of key variables describing general characteristics of the firms, its main financing variables, as well as initial financing ratios. Furthermore, we define two versions of the financial crisis dummy: the first specification (A) covers the early years of the crisis namely 2008 and 2009; the second specification (B) covers the later years, i.e. the 2009 and 2010 period. The precise definitions of all variables used are described in table 1 .

Insert table 1 about here

One of the main objectives of the present paper is to analyze the impact of financial constraints on the financing and investment decisions of the firms, in general, and during the financial crisis, in particular. Nevertheless, there does not exist any objective indicator for financial constraints. Against this background, the literature has developed various approaches to deal with this lack. One idea is to create indexes which combine different proxy variables of financial constraints and group the firms afterwards based on the value of the specific index.

In order to be able to check our results for robustness, we borrow two different measures from the literature which are applicable to our set-up: the indices of Whited and $\mathrm{Wu}(2006)$ and Hadlock and Pierce (2010). Whereas the first index relies on size as well as on information on the financing structure of the respective firm, the latter index is a combination of the size and the age of the firms. In both cases we define a financial constraints dummy by focusing on firms which have values of the index 
in the upper tercile of all observations across all periods, i.e. we consider only those firms as financially constrained which show the most pronounced levels according to these indices. In addition, we also define two one dimensional measures which take into account only one crucial aspect for access to external finance: first, we define a tangibility index which measures the ratio of tangible assets to total assets. In addition, we define a size index based on total assets. In both cases, we define again a financial constraint dummy which takes value on if the firm is in the lower tercile of all observation across all periods. Finally, in order to test our results for robustness, we also define the cut-off levels only with respect to the observations of every single year taking into account that the general situation may change across the years. Hence, overall, we construct eight different financial constraint dummies which we employ later on in our multivariate regression analysis.

Table 2 contains a detailed descriptions of the different concepts employed as well as their precise definitions.

Insert Table 2 about here

\subsection{Sample Description}

Our sample consists of 2456 French firms founded in 2004, 2005, and 2006 located over the entire France. The sample exhibits quite some heterogeneity with respect to general firm characteristics but also with regard to their initial financing structures (see table 3). With median sales of 300TEuro and median total assets of 209TEUR our firms are quite small at the beginning. Though, the large differences between the mean and the median clearly signal that some fairly large firms are present. Though, when looking at relative measures for profitability, our data sample is much less skewed. For example, for the ratio of sales to total assets as well as for net income to total assets, we observe rather similar numbers for the mean and the median. This indicates that our sample contains rather heterogenous firms with respect to size but less so with regard to structure. 
Our newly founded firms are mostly present in the market right from the beginning. Only 40 of them do not have sales throughout the observation period. Nevertheless, we observe a significant portion of firms with negative net income (479) or negative operative income (540 observations). The firms have rather few employees, the median being 3. Most of our firms are in the NAF II 24 and 25 segments that represent the metal-processing and machine-tool industries. However, while there are fewer numbers of firms in the chemical and pharmaceutical industries (codes 20 and 21) and the electronics and electrical industries (codes 26 and 27), we have a significant number of firms in the rubber and plastic industries (codes 22 and 23) as well as in the equipment and automobile industries (codes 28 and 29). More than half of our sample consists of limited-liability firms, while 538 are share firms which allows for a more diverse and flexible ownership.

With respect to the location of our firms we find that they are quite dispersed across France and represent quite well the allocation of population and income in the entire country (with the only exception of the Paris region which is somewhat underrepresented). The firms' founding years are rather evenly distributed over the 2004 to 2006 period indicating that we should not expect any particular biases stemming from firm foundation years.

As a starting point it is worthwhile to have a closer look at the financing patterns of the firms in the year after the firms have been founded, i.e. the year when they present their first regular balance sheet. As table 3 indicates, the firms' main financing source is debt (mean: 0.75, mean: 0.73) being bank loans a considerable proportion (median of bank loan as part of total fundings: 0.11, mean: 0.18). An even more important role is assigned to trade credit which has a mean (median share) in total financing of 0.28 (0.24). Given the notion of pronounced informational asymmetries to be associated with newly founded firms, this degree of debt financing and even more the share of formal bank loan financing seems surprising. We will investigate in the next step to what extent this structure is affected by financial constraints as well as by the financial crisis. 
With respect to the financing and investment decisions in the different years, we get the following picture: trade-credit financing, long-term debt financing as well as total-debt financing growth is generally positive, except in 2009 in which seemingly due to the financial crisis these net financing amounts turn out to be negative, i.e. the firm repays more debt than it takes on new debt. With bank debt, we find in general a negative financing amount in all years, implying that - on average - firms paid rather back the existing debt than accumulated new bank debt. We will turn to this surprising pattern when analyzing the financing dynamics of our newly founded firms in more detail. With respect to investment, we observe a positive net investment in all years with a slight reduction in 2009 and 2010.

\section{Analysis and Results}

\subsection{Financing decisions}

We start our analysis by looking on how the financing decisions of our newly founded firms differ between the more financially and the less financially constrained firms using different measures for financial constraints as outlined above. These measures are always lagged by one period to address potential endogeneity concerns. In a second step, we analyze the effect of the financial crisis on the financing decisions of these firms. In order to differentiate between the supply side and the demand side of the credit shock, we define two different periods of the crisis: A) the years 2008 and 2009 and B) the years 2009 and 2010. We conjecture that the supply shock of credit via a reduced bank lending activity should have been impacted the financial decisions of the firms right from the beginning of the crisis (definition A) whereas a demand shock via a reduction of bank credits demanded by the firms themselves should be reflected in their financing decisions later on (definition B). In a third step, we look on whether the financial crisis had a different impact on the more financially than on the less financially constrained firms. We therefore construct an interaction variable between the financial crisis dummy as well as a dummy variable which indicates whether the firm could be considered financially constrained in the year before the crisis (i.e. in the year 2007 (definition A) or the year 2008 (definition B) based on the different measures 
for financial constraints).

In order to control for further factors which may influence the financing decisions of our firms, we control for size differences by including total assets. In addition, we take potential (beta-)convergence processes into account by including the initial financing ratio (of the respective endogenous variable) one year after the foundation of the company (see Hirsch and Walz (2016)). Finally, to control for unobserved heterogeneity we include region, foundation year as well as industry dummies in our panel regressions. Note that all time-dependent variables are always lagged by one period to address potential endogeneity concerns.

Insert tables 4,5 , and 6 about here

Tables 4 to 7 report our results for the different financing alternatives. We distinguish bank financing, trade credit financing, total long-term debt financing as well as total debt financing in order to be able to give a comprehensive picture of the financing decisions of the firms in general as well as possible substitution effects in particular. Each of the variables is defined as the absolute change in the value of the respective stock between the analyzed year and the previous year. With respect to the control variables, we find an important negative and highly significant impact of the initial financing ratios for bank-financing and long-term debt financing meaning that firms with initially high levels of bak-credit (long-term debt) to total assets use to a lower degree bank-financing (long-term debt financing). This can be explained by the fact that it is a net change, i.e. it also takes into account the repayment of previous credits which lower the bank financing variable. On the other hand, it also points towards the existence of beta-convergence, i.e., firms with a lower initial bank lending (total longterm debt) ratio finance themselves more strongly with bank credit (long-term debt) later on (see Table 4 and 6). Furthermore, we find negative coefficients of the Total Assets variable in the case of trade-credit financing and positive coefficients in the case of total debt financing. In both cases, the coefficients are significant throughout the different specifications (with two exceptions only). This implies that bigger firms use less trade credit financing but more total debt financing. 
With respect to the impact of financial constraints on the financing decisions of the newly founded firms, we find rather straightforward patterns for trade financing and less so for bank-financing.

The more financially constrained firms in our data set use significantly less trade credit financing (only the Tangibility Index does not lead to significant results). This implies that according to our measures, more financially constrained firms rely to a lesser degree on trade credit financing. With regard to bank financing, the coefficients of the financial constraint variables are surprisingly positive. However, it is important to remember that in our descriptive statistics the overall dynamics of bank financing showed negative financing amounts, i.e., on average, firms repaid rather than accumulated bank debt. Hence, it is useful to split our sample in two groups: those firms with negative net bank financing amounts and those with positive ones. When doing so (see Table 8, it turns out that the coefficient of the financial constraint variable is negative in the case of positive bank financing (Panel 1) while being positive with negative bank financing amounts(Panel 2). Since the latter subsample is larger, it seems to overcompensate in the overall sample the former subsample. This finding allows for a much more consistent interpretation. Financially constrained firms repay less debt and accumulate less debt at the same time - a pattern which is quite in line with our observation with respect to the trade credit dynamics. The effects of financial constraints on long-term debt is blurred (see Table 6 ) which is closely connected to our findings on bank financing. Though, if we undertake the same exercise as with bank financing we find in unreported regressions a very similar pattern as with bank financing: financially constrained firms accumulate and repay less long-term debt as compared to their non-financially constrained counterparts.

Insert tables 8 about here

With respect to total debt financing, the coefficients, on the contrary, are negative and highly significant confirming that the more financially constrained firms rely less on external debt financing than the less financially constrained firms. This means that 
the access of financially constrained firms to external debt financing is more limited compared to less financially constrained firms. Thus to sum up, our results indicate that financially constrained firms have been less able to accumulate more external sources of financing during the observation period. Only when other firms paid back bank debt they were - by repaying less - able to stick to a higher level of external financing in this respect.

\section{Insert tables 7 about here}

With respect to the impact of the financial crisis, we distinguish between the supply (regression specification A) and the demand effect (regression specification B) of the credit shock. We can observe in tables 4 to 7 that in the specification A, the coefficient of the financial crisis dummy is negative and almost always significant for all financing instruments with exception of bank credit financing. In the specification B, the coefficient is again negative and significant including bank credit financing. This means that for our firms it was more difficult to rely on external financing during the crisis. But while for trade credit, long-term debt financing and total debt financing, we can observe a reduction during the financial crisis from the beginning, for bank credit financing, we only observe this reduction for the later years. Thus the supply side effect seems to have been more important for trade credit, long-term debt and total debt financing compared to bank credit financing.

Finally, a further crucial aspect is to analyze wether the financial crisis affected the financing decision of firms which were considered more financially constrained before the crisis in a different way than the decisions of firms which were less financially constrained before the crisis. Looking at the coefficients of the interaction term in the different regressions, we get a consistent picture: in most of the different specification the coefficients are positive and highly significant (with exception of the tangibility index regressions). With respect to bank credit financing the results are less robust. A positive coefficient means that financially constrained firms reduce their financing to a lesser degree than non-financially constrained firms during the crisis, i.e. financially constrained firms are less affected by the crisis than non-financially constrained firms. 
To sum up, we can state that the financial crisis reduced the financing amount with respect to all types of financing decisions but while the supply effect does not seem to be the crucial one in case of bank financing, it seems to matter in case of trade credit, long-term debt and total debt financing. In addition, financially constrained firms use less external debt financing. This holds true for all types except bank-financing and long-term debt financing where we have to be more precisely because the net financing amounts is frequently negative. In the case of a negative net financing amount, we find, that financially constrained firms repay less bank credits (or long-term debt) whereas with a positive financing amount, they accumulate less (new) bank credit (or longterm debt). Finally, we can state that the financial crisis had a stronger impact on the financing behavior of non-financially constrained firms than on the behavior of financially constrained firms.

\subsection{The effects of financial constraints and crisis on invest- ment}

We now turn to the analysis of the investment policies of firms putting our focus on the three mentioned aspects: What was the impact of the financial crisis on the investment decisions of our newly founded firms? What is the difference in the investment decisions between more and less financially constrained firms? And finally, are their differences in the impact of the financial crisis on the investment decisions between more and less financially constrained firms?

We aim to answer these questions with a similar multivariate setting as in the previous subsection. Besides the general control variables such as region and industry dummies as well as the foundation year for our newly founded firms, we control for a number of relevant further firm characteristics: the cash flow of the firm in order to control for the internal financing available, the stock of cash in order to control for the liquidity of the firms, net working capital in order to account for the short term requirements of the firm, total debt to total assets in order to control for the capital structure and the total indebtedness of the firm and finally sales to total assets in order to control for the firm's market insertion and strategy. All these variables are lagged 
by one year with respect to the investment decision, i.e. if the investment refers to the investment realized during 2008, the value of the variables is from the balance sheet 2007. In analogy to the financing decisions, we also proxy the investment decisions by total net investment, i.e. the change of fixed assets between the current and the previous year plus the depreciation of the current year.

\section{Insert tables 9 about here}

In a first step, we will analyze whether there exist differences in the investment policy between more and less financially constrained firms. Table 9 shows a negative a highly significant coefficient of our different financial constraint dummy variables (with exception of the Tangibility Index). This means that financially constrained firms invest less than non or, at least, less financially constrained firms.

In a second step, we focus on the impact of the financial crisis on the investment decisions of our newly founded firms. Thereby we distinguish again between the early years of the crisis and the later years of the crisis. The coefficient of the early financial crisis dummy is never significant while the coefficient of the later financial crisis dummy is always negative and highly significant. This means that the financial crisis seemingly led to a reduction in the accumulation of fixed assets. This is very consistent with our findings on the financing side which indicate less debt accumulation during the crisis. But as the impact occurs only in the later years, this clearly speaks against the supply side shock interpretation of our findings but rather points in the direction of a demand shock which is driving down investments.

Finally, we want to analyze whether the impact of the financial crisis on the investment decisions differed between those firms which could be considered financially constrained before the crisis compared to those which were not or less financially constrained before the crisis. Table 9 shows that the coefficient of the interaction term is never significant. This means that the impact of the financial crisis on the investment decisions is the same for financially constrained and non financially constrained firms. 
With respect to the control variables, we obtain the following results: firms with higher total non-current assets, higher cash and higher net working capital invest higher amounts while firms with a higher fixed asset ratio invest lower amounts.

In summary, we find that financially constrained firms invest significantly less than their less financially constrained counterparts. Nevertheless, also the financial crisis led to a crucial reduction in investment, the effect was the same for both financially constrained and non-financially constrained firms.

\section{Conclusion}

The main aim of this paper was to contribute to the literature on the effects of financial constraints and crises on financing and investment decisions of an up to now completely neglected but important part of the corporate universe: newly founded firms. Rather than focusing on the narrow segment of start-up companies, i.e. young, innovative and (very) fast growing companies with potential access to venture capital financing, we use a broader data set which covers newly founded firms of all industries of the manufacturing sector.

We show that the financial crisis reduced overall debt financing as well as the different types of specific financing sources analyzed such as long-term debt, bank as well as trade-credit financing. A similar relation can be observed with respect to financial constraints showing the importance of external finance. We observe a negative effect of financial constraints on overall debt financing as well as trade-credit financing while with bank-financing we observe a slightly more complex pattern. While overall we observe on average repayment of bank debt during our observation period, it turns out that financially constrained firms repay less than their non-financially constrained counterparts. On the upside with the positive accumulation of bank debt, it turns out that financially constrained firms show lower positive net financing amounts of bank debt than the financially non-constrained firms which accumulate more bank debt. It is also interesting to see that the financially constrained firms in our data set were affected to a smaller degree by the financial crisis than their counterparts. With respect to the investment decisions, we get a consistent picture: the financial crisis reduced 
the investment levels though to a lower degree compared with the reduction caused by financial constraints. In addition, we do not find any differences in the impact of the financial crisis on the investment behavior of financially and non financially constrained firms.

There are a number of shortcomings with our analysis. First one would like to know more about the financing counterparts, in particular the banks to get a better understanding on the precise transmission mechanisms through which financial constraints and the financial crisis affected the dynamics of bank lending of the newly founded firms. Furthermore, more information on the financing alternatives which the owners of the firms have - say, e.g., via private finance - would allow to get further insights into the needs for outside financing and hence, a more granular view on financial constraint measures. Despite, these drawbacks, we think that our analysis provides significant insights and contributes importantly to a better understanding of the financing and investment policies of newly founded firms in the wake of external shocks and constraints. 


\section{References}

Adrian, T., Colla, P. and Song Shin, H. (2013). Which financial frictions? parsing the evidence from the financial crisis of 2007 to 2009. NBER Macroeconomics Annual, 27 (1), 159-214.

Almeida, H. and Campello, M. (2007). Financial constraints, asset tangibility, and corporate investment. The Review of Financial Studies, 20 (5), 1429-1460.

Altares (2015). Altares: France, http://international.altares.fr/fichepays/france069.jsp, retrieved Dec. 28, 2015.

Banerjee, A. V. and Duflo, E. (2014). Do firms want to borrow more? testing credit constraints using a directed lending program. Review of Economic Studies, $81(2), 572-607$.

Bottazzi, G., Secchi, A. and Tamagni, F. (2014). Financial constraints and firm dynamics. Small Business Economics, 42 (1), 99-116.

Campello, M., Graham, J. R. and Harvey, C. R. (2010). The real effects of financial constraints: Evidence from a financial crisis. Journal of Financial Economics, 97 (3), 470-487.

Chava, S. and Purnanandam, A. (2011). The effect of banking crisis on bankdependent borrowers. Journal of Financial Economics, 99 (1), 116-135.

Czarnitzki, D. and Hottenrott, H. (2011). R\&d investment and financing constraints of small and medium-sized firms. Small Business Economics, 36 (1), 65-83.

Denis, D. J. (2004). Entrepreneurial finance: an overview of the issues and evidence. Journal of corporate finance, 10 (2), 301-326.

Duchin, R., Ozbas, O. and Sensoy, B. A. (2010). Costly external finance, corporate investment, and the subprime mortgage credit crisis. Journal of Financial Economics, 97 (3), 418-435.

Farre-Mensa, J. and Ljungqvist, A. (2016). Do measures of financial constraints measure financial constraints? The Review of Financial Studies, 29 (2), 271-308. 
Hadlock, C. J. and Pierce, J. R. (2010). New evidence on measuring financial constraints: Mowing beyond the kz index. Review of Financial Stuides, 23 (5), 1909 1940.

Hennessy, C. A., Levy, A. and Whited, T. M. (2007). Testing q theory with financing frictions. Journal of Financial Economics, 83 (3), 691-717.

Hirsch, J. and WAlz, U. (2016). The financing dynamics of newly founded firms. Tech. rep., SAFE Working Paper Series.

Kahle, K. M. and Stulz, R. M. (2013). Access to capital, investment, and the financial crisis. Journal of Financial Economics, 110 (2), 280-299.

Kaplan, S. N. and Zingales, L. (1997). Do investment-cash flow sensitivities provide useful measures of financing constraints? The quarterly journal of economics, 112 (1), 169-215.

Kortum, S. and Lerner, J. (2001). Does venture capital spur innovation? In Entrepreneurial inputs and outcomes: New studies of entrepreneurship in the United States, Emerald Group Publishing Limited, pp. 1-44.

LI, D. (2011). Financial constraints, r\&d investment, and stock returns. The Review of Financial Studies, 24 (9), 2974-3007.

Livdan, H. S., Dmitry and Zhang, L. (2009). Financially constrained stock returns. Journal of FinanceFinance, 64 (3), 1827-1862.

SPAF (2015). Service public de l'administration francoise: D p t des comptes sociaux d'une socit commerciale, https://www.service-public.fr/professionnelsentreprises/vosdroits/F31214, retrieved Dec. 28, 2015.

Whited, T. M. and Wu, G. (2006). Financial constraints risk. Review of Financial Stuides, 19 (2), 531-556. 
Table 1: Variable description

This table provides an overview of the main variables used in the paper

\begin{tabular}{|c|c|}
\hline Variable & Variable description \\
\hline \multicolumn{2}{|r|}{ General characteristics } \\
\hline Sales & Gross sales minus discounts and allowances \\
\hline Total assets & Total size of the balance sheet \\
\hline Fixed assets & Sum of tangible and intangible fixed assets \\
\hline Cash & Cash and other liquid assets \\
\hline Cash flow & Net income + depreciation \\
\hline Net working capital & Current assets - current liabilities \\
\hline Operative income & Net income ex financial income \\
\hline Net income & net profits after taxes \\
\hline \multicolumn{2}{|r|}{ Financing and investment variables } \\
\hline Bank financing & Change in the amount of loans from credit institutions between the year i+1 and year i. \\
\hline Trade credit financing & Change in the amount of accounts payable and short-term debt between the year $i+1$ and year $i$. \\
\hline Long-term debt financing & Change in the amount of obligations and long-term credit between the year $\mathrm{i}+1$ and year $\mathrm{i}$. \\
\hline Total debt financing & Change in the amount of total liabilities between the year $i+1$ and year $i$. \\
\hline Net investment & Change in fixed assets between year $\mathrm{i}$ and year $\mathrm{i}+1$ plus the depreciation of year $\mathrm{i}+1$ \\
\hline \multicolumn{2}{|r|}{ Initial financing ratios } \\
\hline Initial Bank Ratio & Loans from credit institutions / Total assets one year after foundation of the company. \\
\hline Initial Trade Credit Ratio & $\begin{array}{l}\text { Accounts payable and short-term debt by other companies / Total assets one year after } \\
\text { foundation of the company. }\end{array}$ \\
\hline Initial LTD Ratio & Obligations and long-term credit / Total assets one year after foundation of the company. \\
\hline Initial STD Ratio & Short-term debt / Total assets one year after foundation of the company. \\
\hline Initial Total Debt Ratio & Total liabilities / Total assets one year after foundation of the company. \\
\hline \multicolumn{2}{|r|}{ Financial crisis and financial constraints } \\
\hline Financial Constraint & Time variant dummy variable based on the different measures for financial constraints (see table 2) \\
\hline Financial Crisis A & $\begin{array}{l}\text { Dummy variable which takes value } 1 \text { for the financing decisions which were realized during the early crisis, } \\
\text { i.e. the years } 2008 \text { and } 2009 \text {. }\end{array}$ \\
\hline Financial Crisis B & $\begin{array}{l}\text { Dummy variable which takes value } 1 \text { for the financing decisions which were realized during the later crisis, } \\
\text { i.e. the years } 2009 \text { and } 2010 \text {. }\end{array}$ \\
\hline Interaction A & $\begin{array}{l}\text { Value of the dummy variable financial constraint in the year } 2007 \text { multiplied } \\
\text { with the dummy variable financial crisis A. }\end{array}$ \\
\hline Interaction B & $\begin{array}{l}\text { Value of the dummy variable financial constraint in the year } 2008 \text { multiplied } \\
\text { with the dummy variable financial crisis B. }\end{array}$ \\
\hline
\end{tabular}


Table 2: Description of different measures of financial constraints

This table presents the description of our different measures of financial constraints.

\begin{tabular}{|c|c|}
\hline WW Index & 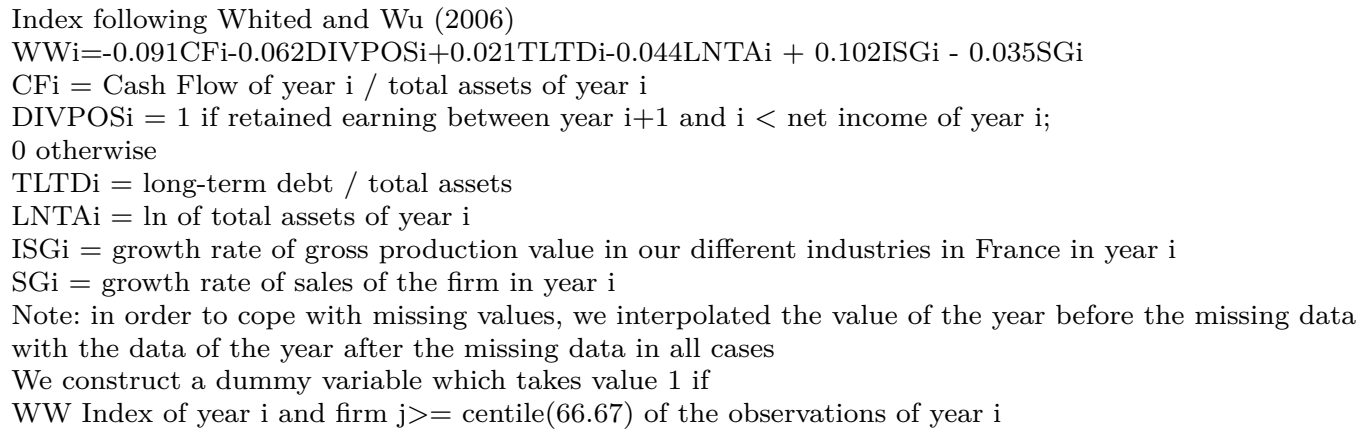 \\
\hline SA Index & $\begin{array}{l}\text { Index following Hadlock and Pierce }(2010) \\
\mathrm{SA}=-0.737 \text { Size }+0.043 \mathrm{Size}^{2}-0.040 \text { Age } \\
\text { Size }=\log \text { of total assets } \\
\text { Age }=\text { actual year }- \text { founding year } \\
\text { We construct a dummy variable which takes value } 1 \text { if } \\
\text { SA index of year } i \text { and firm } \mathrm{j}>=\text { centile(66.67) of the observations of year } \mathrm{i}\end{array}$ \\
\hline Tangibility Index & $\begin{array}{l}\text { Tangibility } i=\text { Tangible fixed assets of year } i / \text { Total assets of year } i \\
\text { We construct a dummy variable which takes value } 1 \text { if } \\
\text { Tangibility Index of year } i \text { and firm } j<\text { centile }(33.33) \text { of the observations of year } i \text {. }\end{array}$ \\
\hline Size Index & $\begin{array}{l}\text { Size }=\text { total assets of year } \mathrm{i} \\
\text { We construct a dummy variable which takes value } 1 \text { if } \\
\text { Size Index of year } \mathrm{i} \text { and firm } \mathrm{j}<\text { centile }(33.33) \text { of the observations of year } \mathrm{i} .\end{array}$ \\
\hline
\end{tabular}


Table 3: Summary statistics

This table presents the summary statistics for all firms of our sample and the most important control variables.

\begin{tabular}{l|cccccc} 
& \multicolumn{7}{|c}{ Year 1 after foundation } \\
Variables & \# obs. & Mean & Median & St.dev. & Min & Max \\
\hline Total assets & 2456 & 2616 & 209 & 34357 & 0 & 1486467 \\
Sales & 2456 & 3095 & 300 & 31014 & 0 & 1133969 \\
Cash to total assets & 2455 & 0.16 & 0.11 & 0.17 & 0 & 1 \\
Sales to total assets & 2455 & 1.72 & 1.61 & 1.04 & 0 & 12.96 \\
Fixed assets to TA & 2455 & 0.26 & 0.21 & 0.22 & 0 & 1.00 \\
Op. income to TA & 2455 & 0.12 & 0.11 & 0.25 & -3.17 & 0.98 \\
Net income to TA & 2455 & 0.10 & 0.09 & 0.21 & -1.42 & 0.81 \\
& & & & & & \\
Actual number & 2456 & 20.31 & 3 & 200.22 & 0 & 6646 \\
of employees & & & & & &
\end{tabular}

\begin{tabular}{l|cl|c} 
& Number of observation & & Number of observation \\
Industry 1 NAF 20+21 & 125 & North of France & 373 \\
Industry 2 NAF 22+23 & 469 & South of France & 520 \\
Industry 3 NAF 23+24 & 1,099 & West of France & 376 \\
Industry 4 NAF 26+27 & 271 & East of France & 634 \\
Industry 5 NAF 28+29 & 491 & Centre of France & 305 \\
\hline & & Region of Paris & 233 \\
Single-member company & 458 & Other Regions & 15 \\
Limited-liability company & 1439 & Year of creation 2004 & 752 \\
Share company & 538 & Year of creation 2005 & 817 \\
\hline Other legal forms & 21 & Year of creation 2006 & 887
\end{tabular}

Initial financing conditions

\begin{tabular}{|c|c|c|c|c|c|c|}
\hline & $\begin{array}{l}\text { Share capital } \\
\text { to total assets }\end{array}$ & $\begin{array}{l}\text { Total debt to } \\
\text { total assets }\end{array}$ & $\begin{array}{l}\text { Long-term debt } \\
\text { to total assets }\end{array}$ & $\begin{array}{c}\text { Loans from credit inst. } \\
\text { to total assets }\end{array}$ & $\begin{array}{l}\text { Trade credits } \\
\text { to total assets }\end{array}$ & $\begin{array}{l}\text { Retained earnings } \\
\text { to total assets }\end{array}$ \\
\hline Mean & 0.15 & 0.73 & 0.28 & 0.18 & 0.25 & 0.06 \\
\hline Median & 0.08 & 0.75 & 0.24 & 0.11 & 0.21 & 0.04 \\
\hline Std. dev. & 0.20 & 0.24 & 0.25 & 0.21 & 0.19 & 0.16 \\
\hline
\end{tabular}

Financing and investment decisions

The mean is indicated and the median in parenthesis. The measures refer to the change in the respective financing in the respective source of financing during the indicated year in TEURO.

\begin{tabular}{l|ccccc} 
& Bank & Trade Credit & Long-term Debt & Total Debt & Investment \\
& Financing & Financing & Financing & Financing & $56.40(10.00)$ \\
2007 & $4.88(0.00)$ & $30.53(3.00)$ & $10.69(0.00)$ & $57.34(9.00)$ & $66.86(9.00)$ \\
2008 & $-1.16(-1.00)$ & $14.26(1.00)$ & $4.74(-1.00)$ & $32.72(1.00)$ & $59.88(8.00)$ \\
2009 & $-4.45(-2.00)$ & $-29.46(-3.00)$ & $-5.68(-3.00)$ & $-26.47(-12.00)$ & $59.56(8.00)$ \\
2010 & $-5.09(-2.00)$ & $18.68(2.00)$ & $0.74(-2.50)$ & $22.75(0.00)$ & $63.73(9.00)$ \\
2012 & $-5.18(-2.00)$ & $25.26(2.00)$ & $4.12(-2.00)$ & $58.52(3.00)$ & $68.92(9.00)$ \\
2013 & $-2.52(0.00)$ & $-1.14(0.00)$ & $3.73(-2.00)$ & $18.44(-1.00)$ & $62.88(9.00)$
\end{tabular}




\section{Table 4: The impact of financial constraints and crisis on bank financing}

This table presents the results of a panel regression with random effects where bank financing is the dependent variable. Bank financing is a flow variable which represents the change in bank-credits from the actual year to the next year. We include a financial crisis dummy, a financial constraint dummy, as well as an interaction dummy between the financial crisis dummy and the value of the financial crisis dummy in the year before the crisis in order to look at the impact of financial constraints on the financing decisions in general and during the crisis in particular. Furthermore, we include Total Assets in order to control for size effects, the initial bank credit ratio which represents Bank Credits to Total Assets one year after foundation in order to control for the initial indebtedness of the firm. Finally, we include industry dummies as well as regional dummies and foundation year dummies as further control variables. We use two different stages of the financial crisis: the early years (2008 and 2009) and the later years (2009 and 2010) in specifications A and B, respectively. In addition, we use different definitions to measure the financial constraints of a firm as described in table 2 . The significance level are indicated with $*, * *, * * *$ for the $10 \%, 5 \%$, and $1 \%$ level, respectively.

\begin{tabular}{|c|c|c|c|c|c|c|c|c|}
\hline $\begin{array}{l}\text { Index } \\
\text { Specification }\end{array}$ & $\begin{array}{c}\text { WW Index } \\
\text { A }\end{array}$ & $\begin{array}{c}\text { WW Index } \\
\text { B }\end{array}$ & $\begin{array}{l}\text { SA Index } \\
\text { A }\end{array}$ & $\begin{array}{l}\text { SA Index } \\
\text { B }\end{array}$ & $\begin{array}{c}\text { Tangibility } \\
\text { A }\end{array}$ & $\begin{array}{c}\text { Tangibility } \\
\text { B }\end{array}$ & $\begin{array}{l}\text { Size } \\
\text { A }\end{array}$ & $\begin{array}{l}\text { Size } \\
\text { B }\end{array}$ \\
\hline Financial Crisis & $\begin{array}{l}-2.43 \\
(1.55)\end{array}$ & $\begin{array}{c}-4.00^{* * *} \\
(1.35)\end{array}$ & $\begin{array}{c}-3.07^{* *} \\
(1.44)\end{array}$ & $\begin{array}{c}-5.06^{* * * *} \\
(1.35)\end{array}$ & $\begin{array}{c}0.44 \\
(1.28)\end{array}$ & $\begin{array}{c}-3.42^{* * *} \\
(1.29)\end{array}$ & $\begin{array}{l}-1.89 \\
(1.34)\end{array}$ & $\begin{array}{c}-4.74^{* * *} \\
(1.30)\end{array}$ \\
\hline Financial Constraints & $\begin{array}{c}0.21 \\
(1.46)\end{array}$ & $\begin{array}{l}-0.08 \\
(1.31)\end{array}$ & $\begin{array}{c}4.02^{* * *} \\
(1.36)\end{array}$ & $\begin{array}{c}3.88^{* * *} \\
(1.34)\end{array}$ & $\begin{array}{c}3.15^{* *} \\
(1.35)\end{array}$ & $\begin{array}{l}2.30^{*} \\
(1.35)\end{array}$ & $\begin{array}{c}4.06 * * * \\
(1.41)\end{array}$ & $\begin{array}{c}3.73^{* * *} \\
(1.41)\end{array}$ \\
\hline Interaction & $\begin{array}{c}2.85 \\
(2.61)\end{array}$ & $\begin{array}{l}4.10^{*} \\
(2.20)\end{array}$ & $\begin{array}{l}4.03^{*} \\
(2.14)\end{array}$ & $\begin{array}{c}4.33^{* *} \\
(2.18)\end{array}$ & $\begin{array}{l}-3.65 \\
(2.27)\end{array}$ & $\begin{array}{c}0.14 \\
(2.25)\end{array}$ & $\begin{array}{c}2.80 \\
(2.18)\end{array}$ & $\begin{array}{l}4.08^{*} \\
(2.23)\end{array}$ \\
\hline Initial Bank Ratio & $\begin{array}{c}-36.62^{* * * *} \\
(3.82)\end{array}$ & $\begin{array}{c}-39.34^{* * *} \\
(3.62)\end{array}$ & $\begin{array}{c}-40.99^{* * * *} \\
(3.33)\end{array}$ & $\begin{array}{c}-40.90^{* * *} \\
(3.34)\end{array}$ & $\begin{array}{c}-40.39 * * * \\
(3.36)\end{array}$ & $\begin{array}{c}-40.14^{* * *} \\
(3.36)\end{array}$ & $\begin{array}{c}-40.82^{* * *} \\
(3.34)\end{array}$ & $\begin{array}{c}-40.80^{* * *} \\
(3.34)\end{array}$ \\
\hline Total Assets & $\begin{array}{c}0.00 \\
(0.00)\end{array}$ & $\begin{array}{c}0.00 \\
(0.00)\end{array}$ & $\begin{array}{c}0.00 \\
(0.00)\end{array}$ & $\begin{array}{c}0.00 \\
(0.00)\end{array}$ & $\begin{array}{c}0.00 \\
(0.00)\end{array}$ & $\begin{array}{c}0.00 \\
(0.00)\end{array}$ & $\begin{array}{c}0.00 \\
(0.00)\end{array}$ & $\begin{array}{c}0.00 \\
(0.00)\end{array}$ \\
\hline Industry dummies & yes & yes & yes & yes & yes & yes & yes & yes \\
\hline Foundation year dummies & yes & yes & yes & yes & yes & yes & yes & yes \\
\hline Region Dummies & yes & yes & yes & yes yes & yes & yes & yes & yes \\
\hline Number of observations & 12069 & 15001 & 16606 & 16612 & 16606 & 16612 & 16613 & 16613 \\
\hline Number of groups & 1783 & 2385 & 2453 & 2454 & 2453 & 2454 & 2454 & 2454 \\
\hline Wald chi2 & 111.55 & 145.46 & 187.11 & 195.73 & 171.74 & 178.62 & 181.56 & 192.06 \\
\hline Prob $>$ chi 2 & 0.0000 & 0.0000 & 0.0000 & 0.0000 & 0.0000 & 0.0000 & 0.0000 & 0.0000 \\
\hline
\end{tabular}

\section{Table 5: The impact of financial constraints and crisis on trade credit financing}

This table presents the results of a panel regression with random effects where trade credit financing is the dependent variable. Trade credit financing is a flow variable which represents the change in trade credits from the actual year to the next year. We include a financial crisis dummy, a financial constraint dummy, as well as an interaction dummy between the financial crisis dummy and the value of the financial crisis dummy in the year before the crisis in order to look at the impact of financial constraints on the financing decisions in general and during the crisis in particular. Furthermore, we include Total Assets in order to control for size effects, the initial bank credit ratio which represents Bank Credits to Total Assets one year after foundation in order to control for the initial indebtedness of the firm. Finally, we include industry dummies as well as regional dummies and foundation year dummies as further control variables. We use two different stages of the financial crisis: the early years (2008 and 2009) and the later years (2009 and 2010) in specifications A and B, respectively. In addition, we use different definitions to measure the financial constraints of a firm as described in table 2 . The significance level are indicated with *,**,*** for the $10 \%, 5 \%$, and $1 \%$ level, respectively.

\begin{tabular}{|c|c|c|c|c|c|c|c|c|}
\hline $\begin{array}{l}\text { Index } \\
\text { Specification }\end{array}$ & $\begin{array}{c}\text { WW Index } \\
\mathrm{A}\end{array}$ & $\begin{array}{c}\text { WW Index } \\
\text { B }\end{array}$ & $\begin{array}{c}\text { SA Index } \\
\text { A }\end{array}$ & $\begin{array}{l}\text { SA Index } \\
\text { B }\end{array}$ & $\begin{array}{c}\text { Tangibility } \\
\text { A }\end{array}$ & $\begin{array}{c}\text { Tangibility } \\
\text { B }\end{array}$ & $\begin{array}{l}\text { Size } \\
\text { A }\end{array}$ & $\begin{array}{l}\text { Size } \\
2\end{array}$ \\
\hline Financial Crisis & $\begin{array}{c}-35.72^{* * *} \\
(4.16)\end{array}$ & $\begin{array}{c}-26.29^{* * *} \\
(3.70)\end{array}$ & $\begin{array}{c}-39.10^{* * *} \\
(4.06)\end{array}$ & $\begin{array}{c}-30.43^{* * *} \\
(3.80)\end{array}$ & $\begin{array}{l}-25.97 \\
(3.62)\end{array}$ & $\begin{array}{c}-21.06^{* * *} \\
(3.63)\end{array}$ & $\begin{array}{c}-35.70^{* * *} \\
(3.78)\end{array}$ & $\begin{array}{c}-29.13^{* * *} \\
(3.68)\end{array}$ \\
\hline Financial Constraint & $\begin{array}{c}-8.58^{* *} \\
(3.92)\end{array}$ & $\begin{array}{l}-6.32^{*} \\
(3.45)\end{array}$ & $\begin{array}{c}-9.97 * * * \\
(3.76)\end{array}$ & $\begin{array}{c}-10.17^{* * *} \\
(3.72)\end{array}$ & $\begin{array}{l}-7.27 \\
(3.69)\end{array}$ & $\begin{array}{l}-5.73 \\
(3.70)\end{array}$ & $\begin{array}{c}-11.96^{* * *} \\
(3.87)\end{array}$ & $\begin{array}{c}-10.64^{* * *} \\
(3.87)\end{array}$ \\
\hline Interaction & $\begin{array}{c}25.64^{* * * *} \\
(6.99)\end{array}$ & $\begin{array}{c}17.25^{* * * *} \\
(5.91)\end{array}$ & $\begin{array}{c}33.83^{* * *} \\
(6.01)\end{array}$ & $\begin{array}{c}25.73^{* * *} \\
(6.14)\end{array}$ & $\begin{array}{c}5.58 \\
(6.37)\end{array}$ & $\begin{array}{c}0.71 \\
(6.33)\end{array}$ & $\begin{array}{c}31.49^{* * *} \\
(6.13)\end{array}$ & $\begin{array}{c}24.71^{* * *} \\
(6.27)\end{array}$ \\
\hline Initial trade credit ratio & $\begin{array}{c}-3.29 \\
(10.83)\end{array}$ & $\begin{array}{c}2.07 \\
(9.14)\end{array}$ & $\begin{array}{c}7.50 \\
(9.34)\end{array}$ & $\begin{array}{c}5.64 \\
(9.35)\end{array}$ & $\begin{array}{c}7.43 \\
(9.24)\end{array}$ & $\begin{array}{c}7.62 \\
(9.29)\end{array}$ & $\begin{array}{c}5.76 \\
(9.36)\end{array}$ & $\begin{array}{c}5.30 \\
(9.39)\end{array}$ \\
\hline Total Assets & $\begin{array}{c}-0.00 \\
(0.00)^{* *}\end{array}$ & $\begin{array}{l}-0.00 \\
(0.00)\end{array}$ & $\begin{array}{c}-0.00^{*} \\
(0.00)\end{array}$ & $\begin{array}{c}-0.00^{* *} * \\
(0.00)\end{array}$ & $\begin{array}{c}0.00 \\
(0.00)\end{array}$ & $\begin{array}{c}-0.00^{* *} \\
(0.00)\end{array}$ & $\begin{array}{c}-0.00^{* *} \\
(0.00)\end{array}$ & $\begin{array}{c}-0.00 * * \\
(0.00)\end{array}$ \\
\hline Industry dummies & yes & yes & yes & yes & yes & yes & yes & yes \\
\hline Foundation year dummies & yes & yes & yes & yes & yes & yes & yes & yes \\
\hline Region Dummies & yes & yes & yes & yes & yes & yes & yes & yes \\
\hline Number of observations & 12055 & 14995 & 16608 & 16614 & 16608 & 16614 & 16615 & 16615 \\
\hline Number of groups & 1780 & 2382 & 2448 & 2449 & 2448 & 2449 & 2449 & 2449 \\
\hline Wald chi2 & 90.80 & 66.28 & 108.24 & 79.11 & 80.28 & 63.08 & 104.01 & 77.58 \\
\hline
\end{tabular}


Table 6: The impact of financial constraints and crisis on long-term debt financing

This table presents the results of a panel regression with random effects where long-term debt financing is the dependent variable. Long-term debt financing is a flow variable which represents the change in bank-credits from the actual year to the next year. We include a financial crisis dummy, a financial constraint dummy, as well as an interaction dummy between the financial crisis dummy and the value of the financial crisis dummy in the year before the crisis in order to look at the impact of financial constraints on the financing decisions in general and during the crisis in particular. Furthermore, we include Total Assets in order to control for size effects, the initial bank credit ratio which represents Bank Credits to Total Assets one year after foundation in order to control for the initial indebtedness of the firm. Finally, we include industry dummies as well as regional dummies and foundation year dummies as further control variables. We use two different stages of the financial crisis: the early years (2008 and 2009) and the later years (2009 and 2010) in specifications A and B, respectively. In addition, we use different definitions to measure the financial constraints of a firm as described in table 2 . The significance level are indicated with $*, * *, * * *$ for the $10 \%, 5 \%$, and $1 \%$ level, respectively.

\begin{tabular}{|c|c|c|c|c|c|c|c|c|}
\hline $\begin{array}{l}\text { Index } \\
\text { Specification }\end{array}$ & $\begin{array}{c}\text { WW Index } \\
\text { A }\end{array}$ & $\begin{array}{c}\text { WW Index } \\
\text { B }\end{array}$ & $\begin{array}{l}\text { SA Index } \\
\text { A }\end{array}$ & $\begin{array}{l}\text { SA Index } \\
\text { B }\end{array}$ & $\begin{array}{c}\text { Tangibility } \\
\text { A }\end{array}$ & $\begin{array}{c}\text { Tangibility } \\
\text { B }\end{array}$ & $\begin{array}{c}\text { Size } \\
\text { A }\end{array}$ & $\begin{array}{c}\text { Size } \\
\text { B }\end{array}$ \\
\hline Financial Crisis & $\begin{array}{c}-11.99^{* * *} \\
(3.15)\end{array}$ & $\begin{array}{c}-10.49^{* * *} \\
(2.75)\end{array}$ & $\begin{array}{c}-10.79^{* * *} \\
(2.97)\end{array}$ & $\begin{array}{c}-11.77^{* * *} \\
(2.78)\end{array}$ & $\begin{array}{c}-4.54 \\
(2.65)\end{array}$ & $\begin{array}{c}-7.94^{* * *} \\
(2.65)\end{array}$ & $\begin{array}{c}-8.98^{* * *} \\
(2.76)\end{array}$ & $\begin{array}{c}-11.27^{* * *} \\
(2.68)\end{array}$ \\
\hline Financial Constraint & $\begin{array}{c}-5.86^{*} \\
(3.16)\end{array}$ & $\begin{array}{c}-5.05^{*} \\
(2.74)\end{array}$ & $\begin{array}{l}-0.25 \\
(2.96)\end{array}$ & $\begin{array}{l}-0.37 \\
(2.91)\end{array}$ & $\begin{array}{l}-0.55 \\
(2.90)\end{array}$ & $\begin{array}{l}-1.01 \\
(2.90)\end{array}$ & $\begin{array}{l}-0.18 \\
(3.13)\end{array}$ & $\begin{array}{l}-0.30 \\
(3.11)\end{array}$ \\
\hline Interaction & $\begin{array}{c}13.67^{* *} \\
(5.42)\end{array}$ & $\begin{array}{l}8.30^{*} \\
(4.52)\end{array}$ & $\begin{array}{c}11.83^{* * *} \\
(4.43)\end{array}$ & $\begin{array}{c}10.39 * * \\
(4.51)\end{array}$ & $\begin{array}{l}-2.21 \\
(4.72)\end{array}$ & $\begin{array}{c}0.31 \\
(4.68)\end{array}$ & $\begin{array}{c}10.03^{* *} \\
(4.51)\end{array}$ & $\begin{array}{c}10.27^{* *} \\
(4.60)\end{array}$ \\
\hline Initial LTD Ratio & $\begin{array}{c}-33.77^{* * * *} \\
(8.31)\end{array}$ & $\begin{array}{c}-30.16^{* * *} \\
(7.03)\end{array}$ & $\begin{array}{c}-38.03^{* * *} \\
(6.55)\end{array}$ & $\begin{array}{c}-37.87 * * * \\
(6.56)\end{array}$ & $\begin{array}{r}-38.11 \\
(6.58)\end{array}$ & $\begin{array}{c}-37.93 * * * \\
(6.58)\end{array}$ & $\begin{array}{c}-37.85 * * * \\
(6.54)\end{array}$ & $\begin{array}{c}-37.85 * * * \\
(6.56)\end{array}$ \\
\hline Total Assets & $\begin{array}{c}0.00^{* * * *} \\
(0.00)\end{array}$ & $\begin{array}{c}0.00 * * * \\
(0.00)\end{array}$ & $\begin{array}{c}0.00 * * * \\
(0.00)\end{array}$ & $\begin{array}{c}0.00 * * * \\
(0.00)\end{array}$ & $\begin{array}{c}0.00 \\
(0.00)\end{array}$ & $\begin{array}{c}0.00^{* * *} \\
(0.00)\end{array}$ & $\begin{array}{c}0.00 * * * \\
(0.00)\end{array}$ & $\begin{array}{c}0.00^{* * *} \\
(0.00)\end{array}$ \\
\hline Industry dummies & yes & yes & yes & yes & yes & yes & yes & yes \\
\hline Foundation year dummies & yes & yes & yes & yes & yes & yes & yes & yes \\
\hline Region Dummies & yes & yes & yes & yes & yes & yes & yes & yes \\
\hline Number of observations & 12077 & 15013 & 16606 & 16612 & 16606 & 16612 & 16613 & 16613 \\
\hline Number of groups & 1783 & 2385 & 2451 & 2452 & 2451 & 2452 & 2452 & 2452 \\
\hline Wald chi2 & 152.40 & 158.12 & 154.61 & 159.22 & 146.73 & 153.44 & 152.01 & 158.78 \\
\hline
\end{tabular}

\section{Table 7: The impact of financial constraints and crisis on total debt financing}

This table presents the results of a panel regression with random effects where total debt financing is the dependent variable. Total debt financing is a flow variable which represents the change in bank-credits from the actual year to the next year. We include a financial crisis dummy, a financial constraint dummy, as well as an interaction dummy between the financial crisis dummy and the value of the financial crisis dummy in the year before the crisis in order to look at the impact of financial constraints on the financing decisions in general and during the crisis in particular. Furthermore, we include Total Assets in order to control for size effects, the initial bank credit ratio which represents Bank Credits to Total Assets one year after foundation in order to control for the initial indebtedness of the firm. Finally, we include industry dummies as well as regional dummies and foundation year dummies as further control variables. We use two different stages of the financial crisis: the early years (2008 and 2009) and the later years (2009 and 2010) in specifications A and B, respectively. In addition, we use different definitions to measure the financial constraints of a firm as described in table 2 . The significance level are indicated with *,**,*** for the $10 \%, 5 \%$, and $1 \%$ level, respectively.

\begin{tabular}{|c|c|c|c|c|c|c|c|c|}
\hline $\begin{array}{l}\text { Index } \\
\text { Specification }\end{array}$ & $\begin{array}{c}\text { WW Index } \\
\text { A }\end{array}$ & $\begin{array}{c}\text { WW Index } \\
\text { B }\end{array}$ & $\begin{array}{c}\text { SA Index } \\
\text { A }\end{array}$ & $\begin{array}{l}\text { SA Index } \\
\text { B }\end{array}$ & $\begin{array}{c}\text { Tangibility } \\
\text { A }\end{array}$ & $\begin{array}{c}\text { Tangibility } \\
\text { B }\end{array}$ & $\begin{array}{c}\text { Size } \\
\text { A } \\
\end{array}$ & $\begin{array}{c}\text { Size } \\
\text { B } \\
\end{array}$ \\
\hline Financial Crisis & $\begin{array}{c}-56.59^{* * *} \\
(7.28)\end{array}$ & $\begin{array}{c}-52.52^{* * *} \\
(6.34)\end{array}$ & $\begin{array}{c}-57.29^{* * *} \\
(6.97)\end{array}$ & $\begin{array}{c}-57.23^{* * *} \\
(6.50)\end{array}$ & $\begin{array}{c}-35.93^{* * *} \\
(6.22)\end{array}$ & $\begin{array}{c}-41.92^{* * *} \\
(6.21)\end{array}$ & $\begin{array}{c}-51.26^{* * *} \\
(6.48)\end{array}$ & $\begin{array}{c}-55.76^{* * *} \\
(6.29)\end{array}$ \\
\hline Financial Constraint & $\begin{array}{c}-19.80^{* * * *} \\
(7.17)\end{array}$ & $\begin{array}{c}-19.22^{* * *} \\
(6.20)\end{array}$ & $\begin{array}{c}-15.08^{* *} \\
(6.81)\end{array}$ & $\begin{array}{c}-16.28^{* *} \\
(6.71)\end{array}$ & $\begin{array}{c}-16.15^{* *} \\
(6.69)\end{array}$ & $\begin{array}{c}-15.08^{* *} \\
(6.67)\end{array}$ & $\begin{array}{c}-20.38^{* * *} \\
(7.16)\end{array}$ & $\begin{array}{c}-20.54^{* * *} \\
(7.12)\end{array}$ \\
\hline Interaction & $\begin{array}{c}42.70^{* * *} \\
(12.44)\end{array}$ & $\begin{array}{c}36.28^{* * *} \\
(10.34)\end{array}$ & $\begin{array}{c}55.36^{* * *} \\
(10.38)\end{array}$ & $\begin{array}{c}47.58^{* * *} \\
(10.57)\end{array}$ & $\begin{array}{c}9.60 \\
(11.04)\end{array}$ & $\begin{array}{c}7.57 \\
(10.93)\end{array}$ & $\begin{array}{c}50.64^{* * *} \\
(10.57)\end{array}$ & $\begin{array}{c}48.53^{* * *} \\
(10.78)\end{array}$ \\
\hline Initial Total Debt Ratio & $\begin{array}{c}-13.06 \\
(18.69)\end{array}$ & $\begin{array}{l}-13.66 \\
(15.73)\end{array}$ & $\begin{array}{l}-28.74^{*} \\
(15.33)\end{array}$ & $\begin{array}{c}-29.66^{*} \\
(15.31)\end{array}$ & $\begin{array}{c}-30.92^{* *} \\
(15.35)\end{array}$ & $\begin{array}{c}-30.73^{* *} \\
(15.32)\end{array}$ & $\begin{array}{l}-29.76^{*} \\
(15.33)\end{array}$ & $\begin{array}{c}-30.46^{* *} \\
(15.32)\end{array}$ \\
\hline Total Assets & $\begin{array}{c}0.00 * * * \\
(0.00)\end{array}$ & $\begin{array}{c}0.00 * * * \\
(0.00)\end{array}$ & $\begin{array}{c}0.00^{* * * *} \\
(0.00)\end{array}$ & $\begin{array}{c}0.00^{* * * *} \\
(0.00)\end{array}$ & $\begin{array}{c}0.00 * * * \\
(0.00)\end{array}$ & $\begin{array}{c}0.00 * * * \\
(0.00)\end{array}$ & $\begin{array}{c}0.00 * * * \\
(0.00)\end{array}$ & $\begin{array}{c}0.00 * * * \\
(0.00)\end{array}$ \\
\hline Industry dummies & yes & yes & yes & yes & yes & yes & yes & yes \\
\hline Foundation year dummies & yes & yes & yes & yes & yes & yes & yes & yes \\
\hline Region Dummies & yes & yes & yes & yes & yes & yes & yes & yes \\
\hline Number of observations & 12066 & 15011 & 16608 & 16614 & 16608 & 16614 & 16615 & 16615 \\
\hline Number of groups & 1779 & 2381 & 2448 & 2449 & 2448 & 2449 & 2449 & 2449 \\
\hline Wald chi2 & 93.37 & 110.34 & 110.03 & 121.01 & 87.06 & 104.99 & 105.69 & 122.21 \\
\hline
\end{tabular}




\section{Table 8: The impact of financial constraints and crisis on bank financing: Sample split}

This table presents the results of a panel regression with random effects where bank financing is the dependent variable. Bank financing is a flow variable which represents the change in bank-credits from the actual year to the next year. We include a financial crisis dummy, a financial constraint dummy, as well as an interaction dummy between the financial crisis dummy and the value of the financial crisis dummy in the year before the crisis in order to look at the impact of financial constraints on the financing decisions in general and during the crisis in particular. We include firm characteristics, industry dummies as well as regional dummies and foundation year dummies as further control variables. We use two different stages of the financial crisis: the early years (2008 and 2009) and the later years (2009 and 2010) in specifications A and B, respectively. In addition, we use different definitions to measure the financial constraints of a firm as described in table 2 . The significance level are indicated with $*, * *, * *$ for the $10 \%, 5 \%$, and $1 \%$ level, respectively. We subdivide our sample in two parts. In Panel A we only look at those observations where the bank financing variable is positive (i.e. bank credit is expanding in size), while in panel B, we include only those observations where the bank financing variable is negative (i.e. bank credit decreases in size).

Panel 1: Positive amounts of net bank financing

\begin{tabular}{|c|c|c|c|c|c|c|c|c|}
\hline $\begin{array}{l}\text { Index } \\
\text { Specification }\end{array}$ & $\begin{array}{c}\text { WW Index } \\
\text { A }\end{array}$ & $\begin{array}{c}\text { WW Index } \\
\text { B }\end{array}$ & $\begin{array}{l}\text { SA Index } \\
\text { A }\end{array}$ & $\begin{array}{l}\text { SA Index } \\
\text { B }\end{array}$ & $\begin{array}{c}\text { Tangibility } \\
\text { A }\end{array}$ & $\begin{array}{c}\text { Tangibility } \\
\text { B }\end{array}$ & $\begin{array}{c}\text { Size } \\
\text { A }\end{array}$ & $\begin{array}{c}\text { Size } \\
\text { B }\end{array}$ \\
\hline Financial Constraints & $\begin{array}{c}-30.79^{* * *} \\
(3.46)\end{array}$ & $\begin{array}{c}-30.09 * * * \\
(3.06)\end{array}$ & $\begin{array}{c}-34.59^{* * * *} \\
(3.07)\end{array}$ & $\begin{array}{c}-36.44^{* * *} \\
(3.05)\end{array}$ & $\begin{array}{l}-4.84 \\
(3.14)\end{array}$ & $\begin{array}{l}-4.64 \\
(3.16)\end{array}$ & $\begin{array}{l}-39.54^{* * *} \\
\quad(3.22)\end{array}$ & $\begin{array}{c}-40.96^{* * *} \\
\quad(3.21)\end{array}$ \\
\hline Financial Crisis & $\begin{array}{c}2.89 \\
(3.47)\end{array}$ & $\begin{array}{c}0.16 \\
(3.06)\end{array}$ & $\begin{array}{c}4.84 \\
(3.21)\end{array}$ & $\begin{array}{l}-2.11 \\
(3.01)\end{array}$ & $\begin{array}{l}-2.45 \\
(2.87)\end{array}$ & $\begin{array}{l}-2.37 \\
(2.94)\end{array}$ & $\begin{array}{c}1.01 \\
(2.99)\end{array}$ & $\begin{array}{l}-2.46 \\
(2.92)\end{array}$ \\
\hline Interaction & $\begin{array}{c}-10.57^{*} \\
(5.96)\end{array}$ & $\begin{array}{c}-11.25^{* *} \\
(5.21)\end{array}$ & $\begin{array}{c}-8.51^{*} \\
(4.91)\end{array}$ & $\begin{array}{l}-1.17 \\
(5.29)\end{array}$ & $\begin{array}{c}2.32 \\
(5.45)\end{array}$ & $\begin{array}{c}1.33 \\
(5.54)\end{array}$ & $\begin{array}{l}-5.52 \\
(5.06)\end{array}$ & $\begin{array}{l}-0.46 \\
(5.41)\end{array}$ \\
\hline Firm characteristics & Yes & Yes & Yes & Yes & Yes & Yes & Yes & Yes \\
\hline Foundation year dummies & Yes & Yes & Yes & Yes & Yes & Yes & Yes & Yes \\
\hline Region Dummies & Yes & Yes & Yes & Yes & Yes & Yes & Yes & Yes \\
\hline Number of observations & 3158 & 3882 & 4276 & 4276 & 4276 & 4276 & 4276 & 4276 \\
\hline Number of groups & 1427 & 1844 & 1945 & 1945 & 1945 & 1945 & 1945 & 1945 \\
\hline Wald chi2 & 159.20 & 195.06 & 226.98 & 224.52 & 46.41 & 46.42 & 243.61 & 243.79 \\
\hline Prob $>$ chi 2 & 0.0000 & 0.0000 & 0.0000 & 0.0000 & 0.0001 & 0.0001 & 0.0000 & 0.0000 \\
\hline
\end{tabular}

Panel 2: Negative amounts of net bank financing

\begin{tabular}{|c|c|c|c|c|c|c|c|c|}
\hline $\begin{array}{l}\text { Index } \\
\text { Specification }\end{array}$ & $\begin{array}{c}\text { WW Index } \\
\text { A }\end{array}$ & $\begin{array}{c}\text { WW Index } \\
\text { B }\end{array}$ & $\begin{array}{c}\text { SA Index } \\
\text { A }\end{array}$ & $\begin{array}{l}\text { SA Index } \\
\text { B }\end{array}$ & $\begin{array}{c}\text { Tangibility } \\
\text { A }\end{array}$ & $\begin{array}{c}\text { Tangibility } \\
\text { B }\end{array}$ & $\begin{array}{c}\text { Size } \\
\text { A }\end{array}$ & $\begin{array}{c}\text { Size } \\
\text { B }\end{array}$ \\
\hline Financial Constraints & $\begin{array}{c}7.57^{* * *} \\
(1.32)\end{array}$ & $\begin{array}{c}6.26^{* * *} \\
(1.14)\end{array}$ & $\begin{array}{c}14.35^{* * *} \\
(1.37)\end{array}$ & $\begin{array}{c}14.04^{* * *} \\
(1.34)\end{array}$ & $\begin{array}{c}4.36^{* * *} \\
(1.34)\end{array}$ & $\begin{array}{l}3.70^{*} \\
(1.35)\end{array}$ & $\begin{array}{c}17.10^{* * *} \\
(1.53)\end{array}$ & $\begin{array}{c}16.79^{* * * *} \\
(1.52)\end{array}$ \\
\hline Financial Crisis & $\begin{array}{l}-0.47 \\
(1.21)\end{array}$ & $\begin{array}{l}-2.80^{*} \\
(1.05)\end{array}$ & $\begin{array}{c}-2.02^{*} \\
(1.10)\end{array}$ & $\begin{array}{c}-2.72^{*} \\
(1.02)\end{array}$ & $\begin{array}{c}0.82 \\
(0.95)\end{array}$ & $\begin{array}{l}-1.64^{*} \\
(0.95)\end{array}$ & $\begin{array}{l}-0.53 \\
(1.02)\end{array}$ & $\begin{array}{c}-2.35 * * \\
(0.98)\end{array}$ \\
\hline Interaction & $\begin{array}{c}0.26 \\
(2.21)\end{array}$ & $\begin{array}{c}6.09 * * * \\
(1.80)\end{array}$ & $\begin{array}{c}2.64^{* *} \\
(1.73)\end{array}$ & $\begin{array}{c}3.71^{* *} \\
(1.75)\end{array}$ & $\begin{array}{l}-2.14 \\
(1.97)\end{array}$ & $\begin{array}{l}1.15 \\
(1.92)\end{array}$ & $\begin{array}{c}2.08 \\
(1.79)\end{array}$ & $\begin{array}{c}3.53^{* *} \\
(1.80)\end{array}$ \\
\hline Firm characteristics & Yes & Yes & Yes & Yes & Yes & Yes & Yes & Yes \\
\hline Industry dummies & Yes & Yes & Yes & Yes & Yes & Yes & Yes & Yes \\
\hline Foundation year dummies & Yes & Yes & Yes & Yes & Yes & Yes & Yes & Yes \\
\hline Region Dummies & Yes & Yes & Yes & Yes & Yes & Yes & Yes & Yes \\
\hline Number of observations & 6108 & 7682 & 8374 & 8374 & 8374 & 8374 & 8374 & 8374 \\
\hline Number of groups & 1592 & 2108 & 2163 & 2163 & 2163 & 2163 & 2163 & 2163 \\
\hline Wald chi2 & 107.91 & 146.73 & 235.63 & 239.54 & 98.20 & 99.88 & 241.10 & 246.23 \\
\hline Prob $>$ chi 2 & 0.0000 & 0.0000 & 0.0000 & 0.0000 & 0.0000 & 0.0000 & 0.0000 & 0.0000 \\
\hline
\end{tabular}




\section{Table 9: The impact of financial constraints and crisis on investment behavior}

This table presents the results of a panel regression with random effects where net investment is the dependent variable. Net investment is a flow variable which represents the change in fixed assets between year i and year $\mathrm{i}+1$ plus the depreciation of year i+1.We include a financial crisis dummy, a financial constraint dummy, as well as an interaction dummy between the financial crisis dummy and the value of the financial crisis dummy in the year before the crisis in order to look at the impact of financial constraints on the financing decisions in general and during the crisis in particular. Furthermore, we include Cash Flow of year i in order to control for the internal financing available, cash of year i in order to control for the cash available, net working capital of year in order to account for the short term requirements of the firm, total debt to total assets of year i in order to control for the capital structure of the firm, sales to total assets of year i in order to control for the firm's market insertion and strategy. Finally, we include industry dummies as well as regional dummies and foundation year dummies as further control variables. We use two different stages of the financial crisis: the early years (2008 and 2009) and the later years (2009 and 2010) in specifications A and B, respectively. In addition, we use different definitions to measure the financial constraints of a firm as described in table 2 . The significance level are indicated with *,**,*** for the $10 \%, 5 \%$, and $1 \%$ level, respectively.

\begin{tabular}{|c|c|c|c|c|c|c|c|c|}
\hline $\begin{array}{l}\text { Index } \\
\text { Specification }\end{array}$ & $\begin{array}{c}\text { WW Index } \\
\text { A }\end{array}$ & $\begin{array}{c}\text { WW Index } \\
\text { B }\end{array}$ & $\begin{array}{c}\text { SA Index } \\
\text { A }\end{array}$ & $\begin{array}{l}\text { SA Index } \\
\text { B }\end{array}$ & $\begin{array}{c}\text { Tangibility } \\
\text { A }\end{array}$ & $\begin{array}{c}\text { Tangibility } \\
\text { B }\end{array}$ & $\begin{array}{l}\text { Size } \\
\mathrm{A}\end{array}$ & $\begin{array}{c}\text { Size } \\
\text { B }\end{array}$ \\
\hline Financial Crisis & $\begin{array}{c}1.17 \\
(3.28)\end{array}$ & $\begin{array}{c}-4.88^{*} \\
(2.83)\end{array}$ & $\begin{array}{l}6.86^{* *} \\
(3.15)\end{array}$ & $\begin{array}{c}-5.94^{* *} \\
(2.92)\end{array}$ & $\begin{array}{c}2.55 \\
(2.79)\end{array}$ & $\begin{array}{c}-7.12^{* *} \\
(2.79)\end{array}$ & $\begin{array}{c}4.01 \\
(2.92)\end{array}$ & $\begin{array}{c}-6.26^{* *} \\
(2.82)\end{array}$ \\
\hline Financial Constraint & $\begin{array}{c}-12.10^{* * *} \\
(3.56)\end{array}$ & $\begin{array}{c}-13.27^{* * *} \\
(3.07)\end{array}$ & $\begin{array}{c}-16.51^{* * *} \\
(3.62)\end{array}$ & $\begin{array}{c}-17.89^{* * *} \\
(3.54)\end{array}$ & $\begin{array}{l}-3.06 \\
(3.51)\end{array}$ & $\begin{array}{l}-4.77 \\
(3.49)\end{array}$ & $\begin{array}{c}-20.19^{* * *} \\
(4.09)\end{array}$ & $\begin{array}{c}-21.99^{* * *} \\
(4.05)\end{array}$ \\
\hline Interaction & $\begin{array}{l}-4.55 \\
(5.77)\end{array}$ & $\begin{array}{l}-1.69 \\
(4.79)\end{array}$ & $\begin{array}{l}-5.53 \\
(4.72)\end{array}$ & $\begin{array}{c}4.08 \\
(4.80)\end{array}$ & $\begin{array}{c}0.33 \\
(5.06)\end{array}$ & $\begin{array}{l}8.22^{*} \\
(5.00)\end{array}$ & $\begin{array}{l}-2.64 \\
(4.79)\end{array}$ & $\begin{array}{c}5.54 \\
(4.88)\end{array}$ \\
\hline Total Non-Current Assets & $\begin{array}{c}0.02^{* * *} \\
(0.00)\end{array}$ & $\begin{array}{c}0.02^{* * *} \\
(0.00)\end{array}$ & $\begin{array}{c}0.02^{* * *} \\
(0.00)\end{array}$ & $\begin{array}{c}0.02^{* * *} \\
(0.00)\end{array}$ & $\begin{array}{c}0.02^{* * *} \\
(0.00)\end{array}$ & $\begin{array}{c}0.02^{* * *} \\
(0.00)\end{array}$ & $\begin{array}{c}0.02^{* * * *} \\
(0.00)\end{array}$ & $\begin{array}{c}0.02^{* * * *} \\
(0.00)\end{array}$ \\
\hline Cash Flow & $\begin{array}{c}0.00 \\
(0.00)\end{array}$ & $\begin{array}{c}0.00 \\
(0.00)\end{array}$ & $\begin{array}{c}0.01^{* * *} \\
(0.00)\end{array}$ & $\begin{array}{c}0.01^{* * *} \\
(0.00)\end{array}$ & $\begin{array}{c}0.01^{* * *} \\
(0.00)\end{array}$ & $\begin{array}{c}0.01^{* * *} \\
(0.00)\end{array}$ & $\begin{array}{c}0.01^{* * *} \\
(0.00)\end{array}$ & $\begin{array}{c}0.01 * * * \\
(0.00)\end{array}$ \\
\hline Cash & $\begin{array}{c}0.10^{* * *} \\
(0.01)\end{array}$ & $\begin{array}{c}0.10^{* * *} \\
(0.01)\end{array}$ & $\begin{array}{c}0.10^{* * *} * \\
(0.01)\end{array}$ & $\begin{array}{c}0.10^{* * *} \\
(0.01)\end{array}$ & $\begin{array}{c}0.10^{* * *} \\
(0.01)\end{array}$ & $\begin{array}{c}0.10^{* * *} \\
(0.01)\end{array}$ & $\begin{array}{c}0.10^{* * *} \\
(0.01)\end{array}$ & $\begin{array}{c}0.10^{* * *} \\
(0.01)\end{array}$ \\
\hline Net Working Capital & $\begin{array}{c}0.02^{* * *} \\
(0.00)\end{array}$ & $\begin{array}{c}0.02 * * * \\
(0.00)\end{array}$ & $\begin{array}{c}0.01^{* * *} \\
(0.00)\end{array}$ & $\begin{array}{c}0.01^{* * *} \\
(0.00)\end{array}$ & $\begin{array}{c}0.01^{* * *} \\
(0.00)\end{array}$ & $\begin{array}{c}0.01^{* * *} \\
(0.00)\end{array}$ & $\begin{array}{c}0.01^{* * *} \\
(0.00)\end{array}$ & $\begin{array}{c}0.01^{* * *} \\
(0.00)\end{array}$ \\
\hline Fixed Assets to Total Assets & $\begin{array}{c}-33.30 * * * \\
(12.11)\end{array}$ & $\begin{array}{c}-37.62^{* * *} \\
(10.49)\end{array}$ & $\begin{array}{c}-43.10^{* * *} \\
(9.61)\end{array}$ & $\begin{array}{c}-42.45^{* * *} \\
(9.60)\end{array}$ & $\begin{array}{c}-47.23^{* * *} \\
(10.01)\end{array}$ & $\begin{array}{c}-46.90^{* * *} \\
(9.99)\end{array}$ & $\begin{array}{c}-46.16^{* * *} \\
(9.63)\end{array}$ & $\begin{array}{c}-45.48^{* * *} \\
(9.63)\end{array}$ \\
\hline Total Debt to Total Assets & $\begin{array}{l}-3.10 \\
(7.85)\end{array}$ & $\begin{array}{l}-1.96 \\
(6.89)\end{array}$ & $\begin{array}{l}-6.02 \\
(6.51)\end{array}$ & $\begin{array}{l}-4.51 \\
(6.47)\end{array}$ & $\begin{array}{l}-7.91 \\
(6.51)\end{array}$ & $\begin{array}{l}-6.95 \\
(6.47)\end{array}$ & $\begin{array}{l}-7.52 \\
(6.50)\end{array}$ & $\begin{array}{l}-6.66 \\
(6.47)\end{array}$ \\
\hline Sales to Total Assets & $\begin{array}{l}-1.57 \\
(2.34)\end{array}$ & $\begin{array}{l}-1.89 \\
(2.00)\end{array}$ & $\begin{array}{l}-2.44 \\
(1.87)\end{array}$ & $\begin{array}{l}-2.50 \\
(1.87)\end{array}$ & $\begin{array}{l}-3.42 \\
(1.87)\end{array}$ & $\begin{array}{l}-3.48^{*} \\
(1.87)\end{array}$ & $\begin{array}{l}-2.46 \\
(1.88)\end{array}$ & $\begin{array}{l}-2.49 \\
(1.88)\end{array}$ \\
\hline Industry dummies & yes & yes & yes & yes & yes & yes & yes & yes \\
\hline Foundation year dummies & yes & yes & yes & yes & yes & yes & yes & yes \\
\hline Region Dummies & yes & yes & yes & yes & yes & yes & yes & yes \\
\hline Number of observations & 12069 & 15005 & 16607 & 16613 & 16607 & 16613 & 16616 & 16616 \\
\hline Number of groups & 1778 & 2376 & 2443 & 2444 & 2443 & 2444 & 2445 & 2445 \\
\hline Wald chi2 & 1155.92 & 1469.23 & 1442.49 & 1454.18 & 1389.83 & 1409.08 & 1422.30 & 1437.30 \\
\hline Prob $>$ chi 2 & 0.0000 & 0.0000 & 0.0000 & 0.0000 & 0.0000 & 0.0000 & 0.0000 & 0.0000 \\
\hline
\end{tabular}




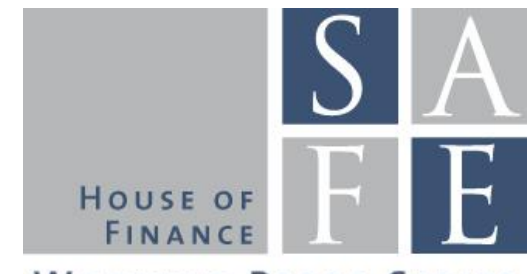

Working PAPER SERIES

\section{Recent Issues}

No. 190 Vanya Horneff, Raimond Maurer, Olivia S. Mitchell

No.189 Carlo Wix

No. 188 Michael Donadelli, Patrick Grüning, Marcus Jüppner, Renatas Kizys

No. 187 Baptiste Massenot, Yuri Pettinicchi

No. 186 Nicole Branger, Paulo Rodrigues, Christian Schlag

No. 185 Patrick Grüning

No.184 Tobias Tröger

No. 183 Joost Driessen, Theo E. Nijman, Zorka Simon

No. 182 Mario Bellia, Loriana Pelizzon, Marti G. Subrahmanyam, Jun Uno, Darya Yuferova

No. 181 Holger Kraft, Farina Weiss

No. 180 Tobias H. Tröger

No. 179 Tobias H. Tröger

No. 178 Matthias Goldmann
How Persistent Low Expected Returns Alter Optimal Life Cycle Saving, Investment, and Retirement Behavior

The Long-Run Real Effects of Banking Crises: Firm-Level Investment Dynamics and the Role of Wage Rigidity

Global Temperature, R\&D Expenditure, and Growth

Can Firms see into the Future?

Survey evidence from Germany

Level and Slope of Volatility Smiles in LongRun Risk Models

Heterogeneity in the Internationalization of R\&D: Implications for Anomalies in Finance and Macroeconomics

Remarks on the German Regulation of Crowdfunding

The Missing Piece of the Puzzle: Liquidity Premiums in Inflation-Indexed Markets

Coming Early to the Party

Consumption-Portfolio Choice with Preferences for Cash

Why MREL Won't Help Much

Too Complex to Work: A Critical Assessment of the Bail-in Tool under the European Bank Recovery and Resolution Regime

United in Diversity? The Relationship between Monetary Policy and Banking Supervision in the Banking Union 